\title{
ASSESSMENT OF NURSES' PERFORMANCE REGARDING CARE OF PATIENTS UNDERGOING CARDIAC CATHETERIZATION
}

\author{
Amal Bakr Abo El-ata, Mariam Sabry Shehab, Rania Nageh El-Zayat \\ Assistant Professor of Medical-Surgical Nursing Faculty of Nursing, Port-Said \\ University, Lecturer in Medical-Surgical Nursing Faculty of Nursing, Port-Said \\ University, B.SC. Nursing, 2005, Faculty of Nursing, Suez Canal University
}

\begin{abstract}
Background: Nurses have a variety of roles and functions associated with the patients' care undergoing cardiac catheterization. Nurses provide care of a patient before, during, and after cardiac catheterization procedure. Aim: This study aimed to assess nurses' performance regarding care of patients undergoing cardiac catheterization. Subjects and Method: A descriptive research design was conducted. Setting: At cardiac catheterization unit at Port Said general hospital in Port-Said City and Al-Azhar university hospital in new Damietta city. Sample: A convenient sample of all available nurses (50) worked at previous mentioned settings. Tools: Three tools were used. Tool (I) Nurses' Knowledge Questionnaire. Tool (II) Observational Checklist. Tool (III) Nurses' Attitude Scale. Results: The result of present study indicated that more than half of studied nurses had satisfactory level of knowledge and practice respectively $(\mathbf{5 2 \%} \% \mathbf{6 2 \%})$ while, most of them (68\%) had positive level of attitude regarding care of patients undergoing cardiac catheterization. Conclusion: More than half of studied nurses had satisfactory knowledge and practice while most of them had positive attitude regarding care of patients undergoing cardiac catheterization. In addition, there were no statistically significant correlation between total nurses' knowledge, practice and attitude scores. Recommendations: There are obvious needs for conducted an educational and training programs to improve nurses knowledge, practice and attitude regarding care of patients undergoing cardiac catheterization.
\end{abstract}

key words: Assessment, Cardiac Catheterization, Nurses' Performance, patients 


\section{INTRODUCTION}

Cardiac catheterization is considering one of the most and famous invasive procedures that can be used to evaluate coronary arteries circulations and determine the status of heart when blood filled the chambers through entering a catheter. Moreover, Marc, 2011 mentioned, cardiac catheterization is used in treatments and diagnosis purposes.

Nurses usually offer care for patient before, during, and after any procedure such as cardiac catheterization and have different roles and functions related to care of such patients. Nurse has a specialized role wherever works as a team member of different surgical health care professionals. Therefore, Absence or limitation of good teaching and preparation pre-operative will increase the necessity for more surgical support to managing underlying medical conditions expected to occur (Vera, 2014).

Cardiac catheterization had several complications that embrace the following: infection, injury and pain at the IV or sheath insertion site, blood clots and harming urinary organ may occur because of the distinction dye that common in kidney disease and patients with DM (Kern, 2011).

Nurse's main goal after procedure is assessment for vascular complications and maintenance of homeostasis at the site of puncture. To achieve these goals the nurse should done effective assessment of patients before cardiac catheterization to identify how to achieve homeostasis at the incision of arteriotomy and diligent monitoring of vital signs. By manual pressure, oozing may be controlled by nurse for 10 minutes and mechanical compression or a pressure dressing at the site of groin (Omran, 2010).

Nurses working in cardiac catheterization units has a specialized role and is a highly skilled cardiovascular nurse whose primary responsibility includes providing nursing care for patients undergoing cardiac catheterization. The first step of responsibilities begin from preadmission and ends with discharge composed of, screening health, preparation of patients' before the surgery, and assistants to surgeon during the surgical procedure, monitoring of patients after the surgery until discharge (Joyce, , Fitzpatrick \&Emerson 2017). 


\section{Significance of the Study:}

In Egypt, (2010) cardiac catheterization complications varies from vascular complications $(2.2 \%)$, arrhythmias $(1.8 \%)$, heart failure $(0.8 \%)$ and myocardium infarction $(2.2 \%)$, in addition to the unpleasant experience for the patients. Therefore, caring for patients undergoing cardiac catheterization requires nurse to have experience and understand the type of complications expected to occur, also the assessment skills to prevent the complications. Therefore, combination between nursing knowledge and skills before, during, and after cardiac catheterization aims to achieve safe and correct procedure, in order to improve mental and physical health (Omran, 2010).

In addition to; nurses working in the cardiac catheterization units play a critical role in management of patients undergoing cardiac catheterization. Many complications for patients undergoing cardiac catheterization such as infection, bleeding, hematoma and thrombosis occur because of Poor performance during nursing care. Therefore, it is very important to assess nurses' performance regarding care of patients undergoing cardiac catheterization. In order to discover the defects and correct it in the future by provision of comprehensive educational and training programs nurses to improve quality of care. (Yassin, 2014).

\section{AIM OF STUDY:}

The study was aimed to assess nurses' performance regarding care of patients undergoing cardiac catheterization. This aim achieved through

- Assess nurses' knowledge regarding care of patients undergoing cardiac catheterization.

- Assess nurses' practice regarding care of patients undergoing cardiac catheterization.

- Assess nurses' attitude regarding care of patients undergoing cardiac catheterization.

\section{SUBJECTS AND METHOD:}

A descriptive research design was used. At cardiac catheterization unit at Port Said general hospital in Port Said City and Al-Azhar university hospital in new Damietta city. A convenient sample of all available nurses worked at previous mentioned settings about (50) nurse. 


\section{TOOLS OF DATA COLLECTION:}

Three tools were used during collection of data:

\section{Tool I: Nurses' Knowledge Questionnaire:}

The tool developed by (Omran, 2010), after reviewing the related literature some modifications were done by the researcher. It was used to assess nurses' knowledge regarding care of patients undergoing cardiac catheterization, and it has consisted of two parts:

\section{PART 1:}

- Socio-demographic data: as, sex, age, level of education and marital status.

- Work related data: as, years of experience, attending training courses regarding cardiac catheterization, number of training courses and presence of protocol in cardiac catheterization unit.

PART 2: It includes (15) closed-ended questions in the form of multiple choices questions, as, definition, purpose, investigations, complications and precautions of cardiac catheterization, preparation of patient and nursing management of patient undergoing cardiac catheterization.

Also include (47) closed-ended questions in the form of true and false, which are divided into: Nurses' knowledge regarding care of patients before cardiac catheterization, include (13) items. Nurses' knowledge regarding care of patients during cardiac catheterization, include (12) item. Nurses' knowledge regarding care of patients after cardiac catheterization, include (14) items. Nurses' knowledge regarding care of patients (health education) undergoing cardiac catheterization include (8) items.

\section{Scoring System for knowledge:}

- Nurses' answers scored on two parts: Part 1: Multiple choose questions (correct $=$ one, incorrect =0). Part 2: Right and wrong questions (right =one, wrong $=0$ ). Total score categorized as satisfactory for a total grade of equal or more than $75 \%$ and unsatisfactory for a total grade of less than 75\% (Eldosoky, 2004 \& Kasem, 2016)

\section{Tool II: Observational Checklist:}

This tool adopted from (Omran, 2010, Williams, and Wilkins, 2011) to assess nurses' practices regarding care of patients undergoing cardiac catheterization, it divided into parts: 
- Nurses' practice before cardiac catheterization, include (9) items

- Nurses' practice during cardiac catheterization, include (3) items

- Nurses' practice after cardiac catheterization, include (6) items

- Nurses' practice regarding care of patients (discharge orders) undergoing cardiac catheterization with the patient and family, include (4) items.

\section{Scoring system of practice:-}

- Scoring system of practice is calculated as following: scoring system scored on two points (done $=2$, not done $=1$, not applicable $=0$ ) Total score categorized as satisfactory for a total grade of equall or more than $75 \%$ and unsatisfactory for a total grade of less than 75\% (Eldosoky, 2004 and Kasem, 2016).

\section{Tool III: Scale to assess nurses' attitude:}

It adapted from (Mathewos, et al., 2013), modifications were performed by the researcher after reviewing the related literature. It used to assess nurses' attitude regarding care of patients undergoing cardiac catheterization. It include (10) closed ended questions, as, Cardiac catheterization is important to cardiac patient, Training on cardiac catheterization is important for behavioral change etc...

\section{Scoring system for attitude Scale:}

- Scoring system of attitude is calculated as following: Scoring system scored on three points (disagree $=$ zero, agree $=1$, strongly agree $=2$ ). Total score categorized as positive for a total grade of equal or more than $75 \%$ and negative for a total grade of less than 75\% (Eldosoky, 2004 and Kasem, 2016).

\section{OPERATIONAL DESIGN}

It includes preparatory phase, tools validity, reliability, pilot study and fieldwork.

\section{A- Preparatory Phase:}

- Done after reviewing literature related to theoretical knowledge of various aspects of the study using books, articles, internet periodicals and magazines to develop the tool for data collection.

\section{B-Tools Validity:}

- It ascertained by a jury of 11 experts from Medical Surgical Nursing and Medicine (Internal Medicine and Cardiovascular Physicians) to review the tools for clarity, relevance, comprehensiveness, understandable, applicable and necessary modifications are done according to the experts' opinions. 


\section{C- Reliability:}

- Cronbach's alpha coefficient is used to assess the internal consistency of tools, Nurses' knowledge questionnaire and its value was (0.964), observational checklist the value for Nurses' practice was $(0.975)$ and the value of Nurses' attitude was (0.923).

\section{D- Pilot study}

- A Pilot study is carried out on $\mathbf{1 0} \%$ of total number of nurses who have been working at Port-Said general hospital and Al-Azhar university hospital. The pilot study was done to test applicability, clarity, relevance and feasibility of study tool and sequence of quotations to maintain consistency. In addition, it used to estimate the time needed to complete the tools. The necessary modifications are done and the final form is developed. The nurses in the pilot study are excluded from the final subjects of the study.

\section{E- Field work}

- The data was collected from all available nurses who have been working at previously mentioned settings and who have been providing direct care to patients undergoing cardiac catheterization. The process was carried out from the beginning of February 2017 to end July 2017.The researcher has meet the nurses individually and explains to them; the purpose and procedure of the study. In addition, obtains oral consent, the researcher questioning the studied nurses for 15-20 minutes and sometimes on separated periods according to duties of nurses and nature of setting to fill in the knowledge questionnaire. The researcher has been available three days per week during early, and late shift.

- As regards attitude, scale was distributed among nurses in (morning and afternoon shifts) and nurses field them by themselves. Each nurse was observed by the researcher before, during and after cardiac catheterization when provide care to the patients. It also carried out during three shifts.

\section{III-ADMINISTRATIVE DESIGN:}

- For conducting of the study, an official requests are issued from the dean of the college of nursing, port said university to the directors of the previously mentioned hospitals to take permission to collect data.

\section{Ethical Considerations:}

- The researcher obtained approval from the nurses to participate in the study

- The researcher to the participants explained aim and objective of the study.

- The researcher ensure the maintenance of anonymity and confidentiality of participants. 
- Participants allowed to choose to participate or not and they have the right to withdrawal from the study at any time without penalty.

\section{VI.STATISTICAL DESIGN:}

Data collected were arranged, tabulated and analyzed according to the type of each data. Data were collected and entered into a database file. Statistical analyses were performed by using the Statistical Package for Social Science (SPSS), version 16. Summary tables described data and figures .Normal distribution was performed on each variable, $p$-value $<0.05$

\section{Data Analysis:}

Spearman correlation was used for assessing correlation between knowledge, practice and attitude. Coefficient of determination $\left(\mathbf{R}^{2}\right)$ was used for assessing the variance in the dependent variable that is predictable from the independent variable. For comparing the (knowledge, practice and attitude) with socio demographic and work related data. Chisquare test $\left(\mathrm{X}^{2}\right)$ was used. Statistical significance was considered at P- Statistically significant at $\mathrm{p}$-value $\leq 0.05$.

\section{Difficulties of the study}

The researcher had the following difficulties while conducting this study:

- Not all studied nurses were available together at the same time, so that the researcher had to work in morning and afternoon shifts to be able to get them all.

- The researcher had to stay in the setting for a long time, and sometimes at late hours, because The nurses were very busy

\section{RESULTS:}

Table (1): Show that the most studied nurse's age were from 20 to less than 30 years old. Concerning to level of education it was observed that the about (32\%) of the studied nurses had a nursing technical institute, while (18\%) of them only had health technical institute. Eventually, the table explains that, slightly more than three quarters (76\%) of the studied nurses were married.

Table (2): Demonstrates that slightly more than two-fifth (42\%) of the studied nurses reported having experience between five to less than ten years. In relation to training courses, $(88 \%)$ of the studied nurses reported attended to training course and more than half $(56 \%)$ of those who attend courses, reported attending twice. Concerning, 
protocol for heart catheter, nearly all of the studied nurses (98\%) reported yes for presence of protocol for cardiac catheter unit.

Table (3): Presents the distribution of the studied nurses according to their level of knowledge regarding care of patients undergoing cardiac catheterization. As noticed in the table, $\mathbf{7 0 \%}$ of the studied nurses had unsatisfactory level of knowledge during cardiac catheterization. The results also, show that, less than two-thirds $(\mathbf{6 2 \%})$ had satisfactory level of knowledge after cardiac catheterization.

Table (4): Indicates distribution of the studied nurses according to their level of practice. As observed in the table, slightly less than half (46\%) of the studied nurses had unsatisfactory level of practice concerning discharge orders about cardiac catheterization. The same table displays that slightly more than three quarters $(76 \%)$ of the studied nurses had satisfactory level of practice regarding to nurses' practice during cardiac catheterization.

Table (5): Adduces that, distribution of the studied nurses according to their attitude. As shown in the table, slightly less than one third (32\%) of the studied nurses had negative level of attitude regarding to item of "total nurses' attitude regarding care of patients undergoing cardiac catheterization", while slightly more than two-thirds $(\mathbf{6 8 \%})$ of them had positive attitude in the same item.

Figure (1): Clarify that, more than half of studied nurses had satisfactory total knowledge and practice while most of them had positive attitude regarding care of patients undergoing cardiac catheterization.

Table (6): This table showed that, there were no statistically significant correlations between total scores of nurses' knowledge, practice and attitude regarding care of patients undergoing cardiac catheterization. 
Table (1): Socio -demographic data of the studied nurses $(n=50)$

\begin{tabular}{|l|c|c|}
\hline \multicolumn{1}{|c|}{ Socio -demographic data } & N & $\%$ \\
\hline & & \\
Age & 22 & 44.0 \\
$30<30$ & 20 & 40.0 \\
$40<50$ & 6 & 12.0 \\
$\quad \geq 50$ & 2 & 4.0 \\
& & \\
\hline Level of education & & \\
Nursing diploma & 13 & 26.0 \\
Nursing technical institute & 16 & 32.0 \\
Health technical institute & 9 & 18.0 \\
Bachelor of nursing & 12 & 24.0 \\
\hline Marital Status & & \\
Single & 9 & 18.0 \\
Married & 38 & 76.0 \\
Divorced & 2 & 4.0 \\
Widowed & 1 & 2.0 \\
\hline
\end{tabular}

Table (2): Work related data of the studied nurses $(n=50)$

\begin{tabular}{|l|c|c|}
\hline \multicolumn{1}{|c|}{ Work related data } & N & $\%$ \\
\hline Experience & 15 & 30.0 \\
$5<5$ & 21 & 42.0 \\
$\geq 10$ & 14 & 28.0 \\
\hline Training courses & & \\
No & 6 & 12.0 \\
Yes & $\mathbf{4 4}$ & $\mathbf{8 8 . 0}$ \\
\hline If Yes number of training courses & 12 & 27.3 \\
1 & 25 & 56.8 \\
2 & 7 & 15.9 \\
3 & & \\
\hline Presence of protocol for cardiac catheter & & 2.0 \\
unit & 49 & 98.0 \\
No & & \\
Yes & & \\
\hline
\end{tabular}


Table (3): Nurses' knowledge regarding care of patients undergoing cardiac catheterization $(n=50)$.

\begin{tabular}{|l|c|c|c|c|}
\hline \multicolumn{1}{|c|}{ Nurses' knowledge } & \multicolumn{2}{|c|}{$\begin{array}{c}\text { Unsatisfactory } \\
(<75 \%)\end{array}$} & \multicolumn{2}{|c|}{$\begin{array}{c}\text { Satisfactory } \\
(\geq 75 \%)\end{array}$} \\
\hline $\begin{array}{l}\text { Nurses' knowledge regarding care of } \\
\text { patients undergoing cardiac catheterization }\end{array}$ & 19 & 38.0 & 31 & 62.0 \\
\hline $\begin{array}{l}\text { Nurses' knowledge regarding care of } \\
\text { patients before cardiac catheterization }\end{array}$ & 34 & 68.0 & 16 & 32.0 \\
\hline $\begin{array}{l}\text { Nurses' knowledge regarding care of } \\
\text { patients during cardiac catheterization }\end{array}$ & 35 & 70.0 & 15 & 30.0 \\
\hline $\begin{array}{l}\text { Nurses' knowledge regarding care of } \\
\text { patients after cardiac catheterization }\end{array}$ & 19 & 38.0 & 31 & 62.0 \\
\hline $\begin{array}{l}\text { Nurses' knowledge regarding care of } \\
\text { patients health education undergoing } \\
\text { cardiac catheterization }\end{array}$ & 28 & 56.0 & 22 & 44.0 \\
\hline
\end{tabular}

Table (4): Nurses' practice regarding care of patients undergoing cardiac catheterization $(n=50)$.

\begin{tabular}{|l|c|c|c|c|}
\hline \multicolumn{1}{|c|}{ Nurses' practice } & \multicolumn{2}{|c|}{$\begin{array}{c}\text { Unsatisfactory } \\
(<75 \%)\end{array}$} & \multicolumn{2}{|c|}{$\begin{array}{c}\text { Satisfactory } \\
(\geq 75 \%)\end{array}$} \\
\hline $\begin{array}{l}\text { - Nurses' practice regarding care of patients } \\
\text { before cardiac catheterization }\end{array}$ & 19 & 38.0 & 31 & 62.0 \\
\hline $\begin{array}{l}\text { - Nurses' practice regarding care of patients } \\
\text { during cardiac catheterization }\end{array}$ & 12 & 24.0 & 38 & 76.0 \\
\hline $\begin{array}{l}\text { - Nurses' practice regarding care of patients } \\
\text { after cardiac catheterization }\end{array}$ & 20 & 40.0 & 30 & 60.0 \\
\hline $\begin{array}{l}\text { - Nurses' practice regarding care of patients } \\
\text { discharge orders undergoing cardiac } \\
\text { catheterization }\end{array}$ & 23 & 46.0 & 27 & 54.0 \\
\hline
\end{tabular}


Table (5): Nurses' attitude regarding care of patients undergoing cardiac catheterization $(n=50)$.

\begin{tabular}{|l|c|c|c|c|}
\hline \multicolumn{1}{|c|}{ Nurses' attitude } & \multicolumn{2}{|c|}{$\begin{array}{c}\text { Positive } \\
(<75 \%)\end{array}$} & \multicolumn{2}{c|}{$\begin{array}{c}\text { Negative } \\
(\geq 75 \%)\end{array}$} \\
\hline & $\mathrm{N}$ & $\%$ & $\mathrm{~N}$ & $\%$ \\
\hline $\begin{array}{l}\text { Nurses' attitude regarding care of patients } \\
\text { undergoing cardiac catheterization }\end{array}$ & 16 & 32.0 & 34 & 68.0 \\
\hline
\end{tabular}

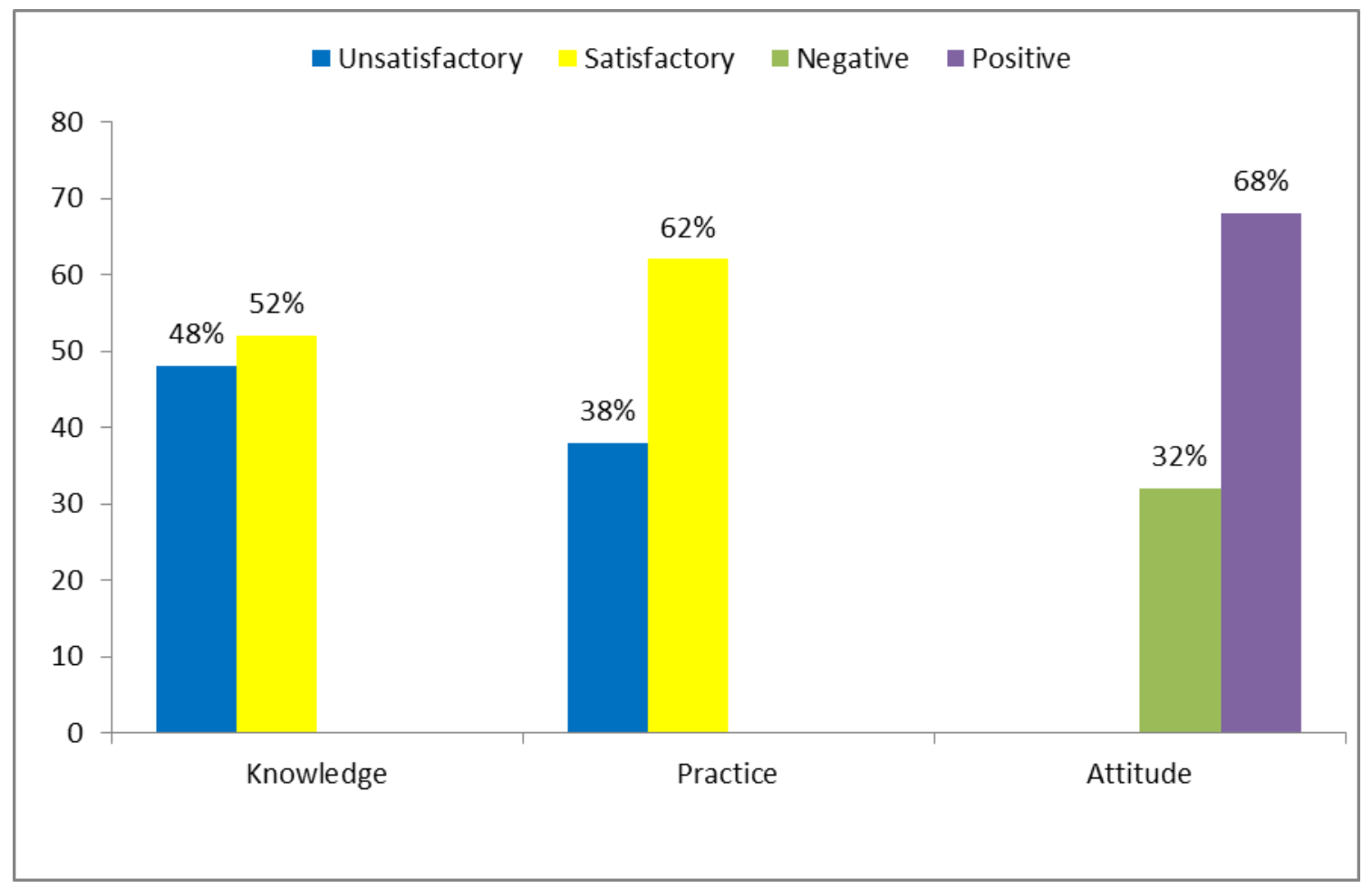

Figure (1): Total nurses' knowledge, practice and attitude regarding care of patients undergoing cardiac catheterization $(n=50)$. 
Table (6): Correlations between total scores of nurses' knowledge, practice, and attitude regarding care of patients undergoing cardiac catheterization.

\begin{tabular}{|c|c|c|c|c|c|c|c|c|c|}
\hline & & al know & edge & & al prac & & & Total att & \\
\hline & R & Sig & $\mathbf{R}^{2}$ & $\mathbf{R}$ & Sig & $\mathbf{R}^{2}$ & $\mathbf{R}$ & Sig & $\mathbf{R}^{2}$ \\
\hline Total knowledge & 1 & & & 0.082 & 0.569 & 0.007 & .251 & 0.078 & 0.063 \\
\hline Total attitude & .251 & 0.078 & 0.063 & 0.074 & 0.608 & 0.005 & 1 & & \\
\hline Total practice & .082 & 0.569 & 0.007 & 1 & & & 0.074 & $\mathbf{0 . 6 0 8}$ & 0.005 \\
\hline
\end{tabular}

$\mathrm{t}, \mathrm{p}: \mathrm{t}$ and $\mathrm{p}$ values for Student t-test

F,p: $\mathrm{F}$ and $\mathrm{p}$ values for ANOVA test

*: Statistically significant at $\mathrm{p} \leq 0.05$

r: Pearson coefficient

\section{DISCUSSION:}

Cardiac catheterization defined as a procedure used in cardiovascular diseases for the purpose of diagnosis and treatments then a long thin tube known as a catheter entered in the artery or vein in the groin area, neck, and arm and threaded to the heart through blood vessels during the insertion of cardiac catheterization (Longo et al., 2015)

Concerning years of experience, it was noticed that high percentage of studied nurses had experience from 5 year to less than 10 years. This might be due to the highest percentage of the studied nurses were juniors. These results were in agreement with Mohammed \& Taha (2014), a study done at critical care areas in Egypt on nurses' knowledge and practice regarding administration of total parenteral nutrition, mentioned that about less than half of the studied sample ranged from 5 year to less than 10 years in years of experience. 
These results is disagree with Ferguson et al., (2016), a study performed in Survey of Cardiovascular Nurses, who mentioned that less than one third of his studied nurses had experience in the field of Anti-Coagulant Drugs that injected before cardiac catheterization procedure. In addition, injection of thrombin by ultrasound guidance is the standard procedure for the treatment of femoral artery Pseudoaneurysm. That is a common vascular complication after cardiac catheterization procedures.

In relation to attending training courses the study was found that most of the studied group mentioned attendance courses about cardiac catheterization training. In addition, more than half of nurses who attend the courses reported attending twice. This may be attributed to their hospital focusing on courses related to cardiac catheterization. This result is in the opposite with Tangiisuran, Tye, \& Leow (2017), a study performed on nurses and general caregivers' knowledge, attitude, and practice on medication administration process (comparison study) who stated; about three-quarters of the study group did not attend any training programs about Anti-Coagulant Drugs or courses.

Concerning nurses' knowledge regarding care of patients before and during cardiac catheterization, the finding revealed that more than half of the studied nurses had unsatisfactory level of knowledge. This might be due to they have inadequate knowledge for patients preparations before cardiac catheterization. In addition work overload, lack of nurses desire to increase their knowledge and deficit nurses needs to update knowledge about critical health problems for nurses working in ICUs for several years.

Study by Feroze, Afzal, Sarwar, Galani \& Afshan (2017) found, more than half of studied nurses had unsatisfactory knowledge regarding patient safety after cardiac catheterization. A study to assess registered nurses' knowledge and practice about patient safety after cardiac catheterization in Punjab institute of cardiology hospital. These results support the current study. On the other hand Rushdy, Youssef \& Elfeky (2015) made a study at Cairo University Hospitals on nurses' knowledge and practice regarding care of patients connected to Intra-Aortic Balloon Pump stated, that more than half of the study group had satisfactory knowledge regarding caring of patients with cardiac procedure. 
According to nurses' knowledge regarding care of patients after cardiac catheterization, the finding revealed that there were less than two thirds of the studied nurses had satisfactory knowledge. This might be due to many factors including motivation of new graduated nurse, most of nurses attending training courses. This result supported by (Ali, 2015), a study regarding implantable cardiac devices in Egypt performed in nurses' knowledge and practice. Who reported that less than two thirds of the studied sample had satisfactory knowledge regarding caring of patients with cardiac procedure. Arathy, (2011), results not matched with finding of the current study who made a study about patient's safety after cardiac catheterization to assess cardiac nurses' knowledge and practices. Concluded that, more than half of the sample participated in the study were unsatisfactory in knowledge after cardiac catheterization regarding patients safety.

In the light of the present study findings the reasons for lack of nurses' knowledge regarding caring of patients undergoing cardiac catheterization, this might be related to lack in absent of continuous supervision and evaluation, and cooperation between multidisciplinary health care team members (nurses - physicians). The point of views of the researcher is supported by a study performed by Degavi, (2013), done on staff nurses working in ICCU of Heart Foundation of KLEs about effectiveness of planned teaching programmed on knowledge regarding cardiac rehabilitation. Found that about half of the studied group pretest were poor level of knowledge while scores of nurses knowledge posttest were satisfactory .

Based on the results more than half of the studied nurses had satisfactory practice regarding care of patients undergoing cardiac catheterization before and after the procedure. In addition, more than three quarters of them also had satisfactory practice regarding practice during cardiac catheterization. This might be due to highest percentage of the studied nurses were juniors. The advantages of nurses in young age group are being hyperactive which is always required in such crucial and vital wards. In addition to some nurses worked by repetition, imitation and experience. This justification discussed in previous study by Arathy, (2011).

This finding in the same line with Aziz, (2014), a study done at Sulaimani Center of Heart Diseases on nurses' practices provided to undergo open-heart surgery patients. Who 
mentioned that most of nurses were satisfactory level in practice about post cardiac procedure. On the other hand Rushdy et al., (2015), stated that nurses' practice were unsatisfactory regarding caring of patients with cardiac procedure. In addition disagree with Feroze et al., (2017), reported that, about more than half of studied sample were unsatisfactory practice after cardiac catheterization regarding patient safety .

The reasons of low practice level in the current study may be related to lack in nurses' confidence, lack in nurses' knowledge and skills. In addition to increase in number of patients and workload. It might be that under reporting between nurses in these units can be explained by the fact that these conditions are not observed greatly. Because, they are not easily detected by variety of hospital personnel. Under reporting also occurs due to fear of interpersonal reactions of physicians, supervisors and patients.

This point of view is supported by Souza, (2015), a study performed on, Patients Receiving Anti-Coagulant Therapy about Effect of Planned Teaching on Knowledge and Practice in The Intensive Care Unit Regarding The Care of Among The Nurses . Who stated the nurses and the nurse practitioners should be equipped with knowledge and skills necessary to prevent complications associated with Anti-Coagulant Drugs. They should be taught how to identify common risk sign and educate how to deal with it, patients service requirements, consider important safety implications to help prevent complications, and discuss patient and family educational needs related to cardiac catheterization. So, it was important for the researcher to apply this study.

Concerning total scores of nurses' attitude regarding to care of patients undergoing cardiac catheterization, this study reveal that most of nurses under study had positive attitude. This might be due to more than half of the studied nurses had good knowledge and practice acquired from training courses, protocol finding in cardiac unit, experience years of work with cardiac patient care undergoing cardiac catheterization.

This point of views support by Feroze et al., (2017), In addition, this result is consistent with Cross et.al, (2017), a study performed on nurses' attitudes toward the single checking of medications. Who mentioned that most of the studied nurses had 
positive attitude toward the single checking of medications. That following cardiac catheterization procedure.

Based on the findings, the researched reported, there were no statistically significant correlations between total scores of nurses' knowledge, practice and attitude regarding care of patients undergoing cardiac catheterization. These results might be due to more than half of studied sample had satisfactory total knowledge and practice and most of them had positive attitude in total score regarding care of patients undergoing cardiac catheterization. In addition, training is considered one way of preventing adverse nursing outcomes. Therefore, to provide high quality care, nurses must have an adequate knowledge that they have actually used in practice. These findings is in accordance with Sayed et al., (2009), a study performed in, Micro Vascular Free Tissue Transfer Surgeries Impact of A Designed Teaching Protocol on Nurse's Performance For Reduction or Prevention of Post-Operative Failure. Found that there were no correlation between nurses' knowledge and practice scores about micro vascular free tissue transfer surgeries.

In the same line with this results a study done at Al-Nassirrhyia Heart Center by Atiyah, (2016), Concerning Pacemaker Implantation for Cardiac Rhythm Disorder on Adult Patients in Nurses Knowledge .Who concluded that there were no correlation between nurses' knowledge and practice scores regarding care of Cardiac Rhythm Disorder in Adult Patients. On the other hand (Ali, 2015), found that there was a strong correlation between total score of nurses knowledge and practice in Egypt Regarding Cardiac Devices implementation .

\section{CONCLUSIONS:}

\section{On the basis of the results, the following can be concluded:}

More than half of studied nurses had satisfactory knowledge and practice while most of them had positive attitude regarding care of patients undergoing cardiac catheterization. In addition, there were no statistically significant correlation between total nurses' knowledge, practice and attitude scores. 


\section{RECOMMENDATIONS:}

After conclusion of the present study, many recommendations can be suggested as:

- Continuous in-service training program to motivate the nurses working in cardiac catheterization unites to achieve the standard of nursing care given to such group of patient and take positive actions to cardiac patients.

- Management of patients undergoing cardiac catheterization should be included in the curriculum of all nursing sectors and institute as a minor specialty.

○ Continuous evaluation of nurses' knowledge, practice and attitude is essential to identify nurses' needs to correct the defect.

- An educational program for nurses to improve the performance about care of patient undergoing cardiac catheterization and assess the impact of this program.

$\circ$ Encourage and help nurses to attend national and international conferences, workshops and training courses affiliated to Ministry of Health related to nursing care for patients undergoing cardiac catheterization.

\section{REFERENCES:-}

Ali, N., (2015). Nurses' Knowledge and Practice Regarding Implantable Cardiac Devices in Egypt. British Journal of Cardiac Nursing. 34, 5-121. 10 (1).

Arathy, S.R., (2011). A Study to Assess The Knowledge and Practices Among Cardiac Nurses About Patients Safety After Cardiac Catheterization. Sree Chitra Tirunal Institute For Medical Sciences and Technology. Code No 6210, Available at: http:// Dspace. Sctimst. Ac. In/ Jspui/ Bitstream/ 123456789/1595/1/46 9.pdf , [Accessed in: 8th Jouly, 2017].

Atiyah, H, (2016): Nurses Knowledge Concerning an Implantation Pacemaker For Adult. Patients with Cardiac Rhythm Disorder at Al-Nassirrhyia Heart Center. Kufa Journal for Nursing Sciences,: 6 (1). 233-238.

Aziz, A., (2014). Evaluation of Nurses' Practices Provided to The Patients Who Undergo Open Heart Surgery In Sulaimani Center of Heart Diseases (SCHD). Kufa Journal for Nursing Sciences, 69-81. 3(1).

Cross. R., Paul N., Ockerby, c., Wang, W. and Currey, J., (2017). Nurses' Attitudes Toward The Single Checking of Medications. World Views on Evidence- 
Based Nursing. Available at: https: //www. ncbi. nlm. nih. gov/pubmed/28437836 DOI: 10.1111/wvn.1220. [Accessed in: 20/7/2017].

Degavi, G., (2013). Effectiveness of planned teaching programme (PTP) on Knowledge Regarding Cardiac Rehabilitation among staff Nurses working in ICCU of Heart Foundation of KLEs Dr. Prabhakar Kore Hospital \& MRC Belgaum (Doctoral dissertation, KLE University, Belgaum, Karnataka). Asian Journal of Nursing Education and Research ISSN: 2349-2996(Online), 2231-1149(Print)

Eldosoky, H., (2004): Assessment of Nurses' Knowledge and Practice about Measures to Prevent Deep Venous Thrombosis Among Hospitalized Patients in General Hospitals At Port-Said city. Un published Master thesis. Faculty of Nursing, Suez Canal University.77-78.

Ferguson, C., Inglis, S.C., Newton, P.J., Middleton, S., Macdonald, P.S. and Davidson, P.M., (2016). Education and Practice Gaps on A Trial Fibrillation and Anticoagulation: A Survey of Cardiovascular Nurses. BMC Medical Education Available at: https://doi.org/10.1186/s12909-015-0504- [Accessed in: 17/2/2017].

Feroze, M., Afzal, M., Sarwar, H., Galani, A., and Afshan, S.h., (2017). Assess Knowledge and Practice of Registered Nurses about Patient Safety after Cardiac Catheterization in Punjab Institute of Cardiology Hospital, Lahore. Journal MPP; V2, N2. 223-238.

Joyce, J., Fitzpatrick, and Emerson, E., (2017). Cardiac Catheterization Nurse Role Available at: Https:// Books. Google. Com. Eg/ Books? Isbn= 0826133088, 40. [Accessed in: Dec. 20, 2017].

Kasem , M. (2016) : Assessment of nurses' performance regarding nursing care of patients undergoing blood transfusion. Un published Master thesis. Faculty of Nursing, Port said University. 83:84.

Kern,M., (2011): Catheterization and Angiography. In: Goldman, L., Schafer, A.I., Eds. Goldman's Cecil Medicine. 24th Ed. Philadelphia, Pa: Saunders Elsevier: Chap 57. 428-433. Available at: https: //www. elsevier. com/ books/ link/ link/ 9780808924371. [Accessed in: jun. 2, 2018]. 
Longo, D.L, Fauci, A.S., Kasper, D.L., Hauser, S.L., Jameson, J., Loscalzo, J., and Fauci, A.S., (2015): Diagnostic Cardiac Catheterization and Coronary Angiography. In: Harrison's Principles of Internal Medicine. 19th Ed. New York, N.Y. Mcgraw- Hill Education; Available at: Http:// Access medicine. Com. [Accessed in: Feb. 24, 2016].

Marc,S.,(2011): Pocket Medicine (4th ed.). Philadelphia: Wolters Kluwer Health/Lippincott Williams and Wilkins. ISBN $\underline{1608319059}$. Available at: www. worldcat. org/title/pocket-medicine/oclc/642278704. [Accessed in: Feb. 12, 2016].

Mohammed, E.K., and Taha, A.S., (2014). Critical Care Nurses' Knowledge and Practice Regarding Administration of Total Parenteral Nutrition at Critical Care Areas in Egypt. Journal of Biology, Agriculture and Healthcare, 4(13), 10-22.

Omran, E.S., (2010). A Study of Nurses Performance Imanagement and Prevention of Complication for Patient Undergoing Cardiac Catheterization. Published Master Thesis, Benha Un., Fac. Nursing, 9-100. Available at: http: //db4. eulc. edu. eg/eulc_v5/Libraries/ Thesis/ Browse Thesis Pages. aspx $? \mathrm{fn}=$ Public Draw Thesis \& BibID $=11267777$. [Accessed in: Feb. 12, 2017].

Rushdy, R., Youssef, Y., and Elfeky, Y., (2015). Nurses' Knowledge and Practice Regarding Care of Patients Connected to Intra-Aortic Balloon Pump at Cairo University Hospitals. Egyptian Journal of Nursing. 5-121. 10 (1).

Sayed, S.M., Ghanem , H.M., Mohamed ,W.Y. and Gamal ,T.A., (2009): Micro Vascular Free Tissue Transfer Surgeries Impact of A Designed Teaching Protocol on Nurse's Performance For Reduction or Prevention of Post Operative Failure. AAM. Journal ,7(3): 20-108.

Souza, M., (2015). Effect of Planned Teaching on Knowledge and Practice Regarding The Care of Patients Receiving Anti-Coagulant Therapy Among The Nurses in The Intensive Care Unit in A Selected Hospital. Asian Journal. Nursing. Education and Research, 5(3): 351-362.

Tangiisuran, B., Tye, S.C., and Leow, M.Y., (2017). Comparison of Nurses and General Caregivers' Knowledge, Attitude, and Practice on Medication Administration Process and Their Distress Level in Long-Term Care Facilities Across Penang, Kuala 
Lumpur, and Selangor of Malaysia. Springer International Publishing: Available at: https://doi.org/10.1007/s40520-017-0772-1. [Accessed in 23/7/2017].

Vera, M., (2014). Client-Nursing-Care-Plans. Available at: Http://Nurseslabs. Com/13-Surgery - Perioperative - [Accessed in: Mar 1, 2014].

Williams, L. and Wilkins, (2011). Taylor's Clinical Nursing Skills: A Nursing Process Approach, $3^{\text {rd }}$ ed., China: 575-585. Available at: http://www. zu.edu.jo/UploadFile/Library/E_Books/Files/LibraryFile_16105_10.pdf [Accessed in: 8th July, 2017].

Yassin, M.S., (2014). Assessment of Nursing Compliance with Standards of Care for Patients Undergoing Cardiac Catheterization. Unpublished Master Thesis, Cairo UN, Fac. Nursing, 7-8. 


\title{
تقييم أداء الممرضين تجاه العناية بالمرضى الخاضعين لقسطرة القلب
}

\author{
رانــــــــــــح الــزيـــات، د/أمل بكر أبو العطا، د/مريم صبري شهاب \\ بكالوريوس تمريض - جامعة قناة السويس O . . r ، أستاذ مساعد التمريض الباطني والجر/حي كلية \\ التهريض - جامعة بورسعيد، مدرس التصريض الباطني والجراحي كلية التصريض- جامعة بورسعيد
}

\section{الـخـلاصــة}

للممرضين دور هام تجاه العناية بالمرضى الخاضعين لقسطرة القلب قبل وأثناء وبعد إجراء قسطرة القلب. لذلك صمدت هذه الدر اسة الوصفية لتقييم أداء الممرضين تجاه العناية بالمرضى الخاضعين لقسطرة القلب. حيث أجريت الدراسة في وحدة قسطرة القلب بمستشفى بورسعيد العام بمدينة بورسعيد ومستشفى الأزهر الجامعي بمدينة دمياط

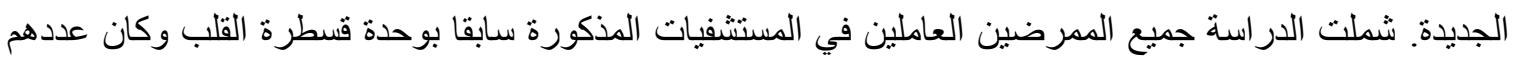
• ه ممرضة. تم استخدام ثلاث أدوات لجمع البيانات. الأداة الأولى استمارة استبيان تتكون من جزئيين، الجزء الأول يتضمن البيانات الثخصية وبيانات العمل للممرضين. الجزء الثناني يحتوي علي أسئلة لتقييم معلومات الممرضين تجاه العناية بالمرضى الخاضعين لقسطرة القلب. الأداة الثانية استمارة ملاحظة ممارسات الممرضين تجاه العناية بالمرضى الخاضعين لقسطرة القلب. الأداة الثالثة مقياس سلوكيات الممرضين تجاه العناية بالمرضى الخاضعين

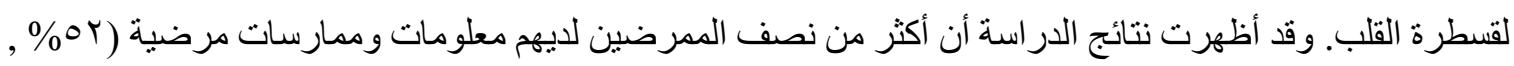

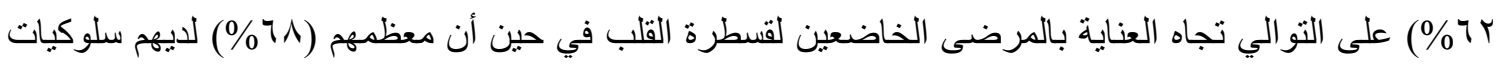
ايجابية تجاه العناية بالمرضى الخاضعين لقسطرة القلب. كما أنة لا يوجد اى ارتباطات ذات دلالة إحصائية بين

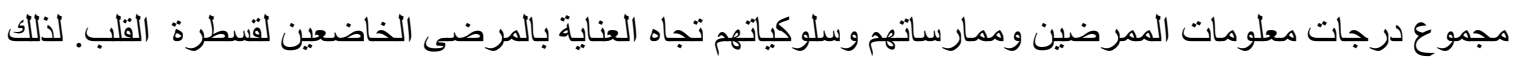
هناك حاجة واضحة لتتفيذ بر امج تعليمية وتدرييية لتحسين معلومات الممرضين وممارساتهم وسلوكياتهم تجاه العناية بالمرضى الخاضعين لقسطرة القلب. 